Gut, 1982, 23, 422-427

Case report

\title{
Alpha heavy chain disease lacking secretory alpha chain, with cobblestone appearance of the small intestine and duodenal ulcer demonstrated by endoscopy
}

\author{
T HIBI, H ASAKURA, K KOBAYASHI, Y MUNAKATA, S KANO, \\ $M$ TSUCHIYA, ${ }^{*}$ T TERAMOTO, and Y UEMATSU
}

From the Department of Medicine and Clinical Laboratory, School of Medicine, Keio University, Tokyo, Japan, and the Department of Surgery, Asikaga Red Cross Hospital, Asikaga, Japan

SUMMARY Ultrastructural and immunohistochemical studies of the small intestine are described in a Japanese patient with alpha heavy chain disease who had a history of colonic ulcers. Endoscopic examinations revealed multiple gastric erosion, duodenal ulcer, and a thickened, cobblestone-like pattern composed of small nodules in the duodenum and jejunum, which was similar in appearance to Crohn's disease. An electron microscopic study showed that the numerous, infiltrated cells in the jejunal lamina propria were matured plasma cells with atypical structure of the organelles. These plasma cells had alpha heavy chain protein devoid of light chain. Although secretory component was demonstrated normally in the epithelial cells by immunofluorescent methods, no association of this component with alpha heavy chain protein could be observed in any of the plasma and epithelial cells of this case. These facts suggest the absence of secretory alpha chain or secretory $\operatorname{IgA}$, and a deficiency of the mucosal secretory immune system in this patient.

Since the first description of alpha heavy chain disease ${ }^{1}$ more than 100 cases have been reported. This disorder appears to be a condition primarily affecting the secretory IgA system of the digestive tract. For studies on the secretory immune system, alpha heavy chain disease represents an appropriate natural model. Whether the binding of secretory component with alpha heavy chain protein in the intestine is present or not in this disorder, however, has not yet been clarified.

The disorder has been observed predominantly in the Mediterranean area and the Middle East. Although a few cases have been reported in other Eastern countries, only two cases have so far been described in Japan. ${ }^{2} 3$

The purpose of this paper is to report a third case of alpha heavy chain disease in Japan, associated

\footnotetext{
* Address for correspondence: Dr M Tsuchiya, Department of Interna Medicine, School of Medicine, Keio University, 35 Shinanumachi Shinjukuku, Tokyo 160, Japan.

Received for publication 14 July 198
}

with multiple gastric erosion and duodenal ulcer. Furthermore, this case was investigated by electron microscopic and immunohistochemical methods in order to clarify the localisation of secretory component in the small intestine.

\section{Case report}

A 39-year-old Japanese male developed occasional diarrhoea associated with lower abdominal pain in March 1975. The next year he suffered from severe diarrhoea. At that time, the possibility of Crohn's disease was considered, as multiple ulcers with a cobblestone-like appearance were demonstrated in the duodenum and ileocecal regions by barium enema radiographs and endoscopic examinations. In July 1977, the patient was admitted to Ashikaga Red Cross Hospital because of severe diarrhoea, abdominal pain, and fever.

Physical examination revealed nothing noteworthy except for abdominal distension. Laboratory 
investigations gave a haemoglobin level of $6.3 \mathrm{~g} / \mathrm{dl}$, white blood cell count of $5100 / \mathrm{mm}^{3}$ (neutrophils $68 \%$, lymphocytes $30 \%$, monocytes $2 \%$, eosinophils $0 \%$, and basophils $0 \%$ ) and platelets $21 \times 10^{4} / \mathrm{mm}^{3}$. Serum electrolytes were within the normal range. The total protein was $4.4 \mathrm{~g} / \mathrm{dl}$ (albumin $41.5 \%$ ), total cholesterol $72 \mathrm{mg} / \mathrm{dl}$, LDH $209 \mathrm{~W}$ units, GOT $18 \mathrm{~K}$ units, GPT $24 \mathrm{~K}$ units, and alkaline phosphatase $10 \cdot 2 \mathrm{KA}$ units.

\section{PROTEIN STUDIES}

Electrophoresis and immunoelectrophoresis were performed by standard methods. Serum immunoglobulins were estimated using radial immunodiffusion methods. Immunoselection methods were performed in $1.2 \%$ agar+agarose mixed gel, incorporated with $10 \%$ anti-lambda and kappa serum (Dekopatts, 500 titre). After electrophoresis for two hours at $2.5 \mathrm{~mA} / \mathrm{cm}$, anti-IgA (alpha chain) and anti-secretory component were loaded and allowed to diffuse overnight.

\section{ENDOSCOPIC EXAMINATIONS}

An Olympus small intestine fibrescope (Olympus SIF-B) was used for observations of the stomach, duodenum, and jejunum. The fibrescope was inserted into the jejunum $30 \mathrm{~cm}$ distal to the ligament of Treitz.

\section{IMMUNOHISTOCHEMICAL STUDIES}

Biopsy specimens from the jejunal mucosa through the Olympus SIF-B were fixed in $95 \%$ ethanol at $4^{\circ} \mathrm{C}$ overnight. After dehydration for three days in absolute ethanol, the tissues were embedded in paraffin and then cut into $4 \mu$ sections. Immunofluorescent studies were performed on these sections, according to the direct methods using monospecific antisera against alpha, gamma, mu, epsilon, kappa, and lambda human chains conjugated to fluorescein isothiocyanate (Behringerwerke, West Germany). Indirect methods using rabbit anti-human secretory component and goat anti-rabbit IgG conjugated with fluorescein isothiocyanate, were used to observe the localisation of secretory component. The specificity was assessed by the blocking test.

\section{ELECTRON MICROSCOPIC EXAMINATIONS}

The biopsied specimens from the jejunal mucosa were fixed with $2 \%$ glutaraldehyde in phosphate buffer and post-fixed with $1 \%$ osmic acid. After dehydration in graded solutions of ethanol, the materials were embedded in Epon 812. Thin sections were stained with uranyl acetate and lead citrate, and observed under a Hitachi HS-9 electron microscope.

\section{Results}

\section{PROTEIN STUDIES}

The serum protein fraction showed a slight decrease in the gamma globulin fraction. The most striking abnormality was a broad rise in the alpha 2 and beta mobility range. Immunoelectrophoretic analysis of the patient's serum demonstrated a heavy and broadly dispersed precipitin arc when the serum was developed with anti-IgA serum. The same arc was discernible in the immunoelectrophoretic pattern of the patient's serum developed with anti-Ig $(G+A+M)$. Precipitin arcs corresponding to the IgA components were not found when the serum was developed with anti-Bence Jones kappa and lambda serum. Investigations by the immunoselection plate method were performed on the patient's serum. The serum did not react to antilambda and kappa serum, and showed the same bands as those seen in the immunoelectrophoresis (Fig. 1).

\section{ENDOSCOPIC EXAMINATIONS}

The gastric mucosa showed multiple erosion with atrophic gastritis, and active ulcer was observed on the anterior wall of the duodenal bulb (Fig. 2). Through the second portion of the duodenum and jejunum, the mucosal surface consisted of nodules resembling cobblestones (Fig. 3). The size of each nodule, however, was smaller than that seen in Crohn's disease and the lesions were diffuse over the section of the intestine that was observed. Microscopically, biopsied specimens revealed villous atrophy with marked reduction in the height of the epithelial cells. The lamina propria was markedly infiltrated by plasmacytoid cells. These plasmacytoid cells showed infiltration into some parts of the submucosa.

\section{IMMUNOHISTOCHEMICAL STUDIES}

The numerous cells infiltrating into the lamina propria exhibited a slight cytoplasmic fluorescence with anti-alpha chain serum (Fig. 4), and a few of them exhibited fluorescence with anti-kappa and lambda chain serum (Fig. 5). Gamma, mu, and epsilon positive cells were sparsely observed in the lamina propria. Moreover, the epithelial cells showed no fluorescence with anti-alpha chain serum, but clear fluorescence with anti-secretory component serum in the apical portions (Fig. 6). The localisation of the secretory component was predominantly in the crypt cells.

\section{ELECTRON MICROSCOPIC EXAMINATIONS}

Almost all of the infiltrating cells into the lamina propria revealed the mature pattern of plasma cells. 


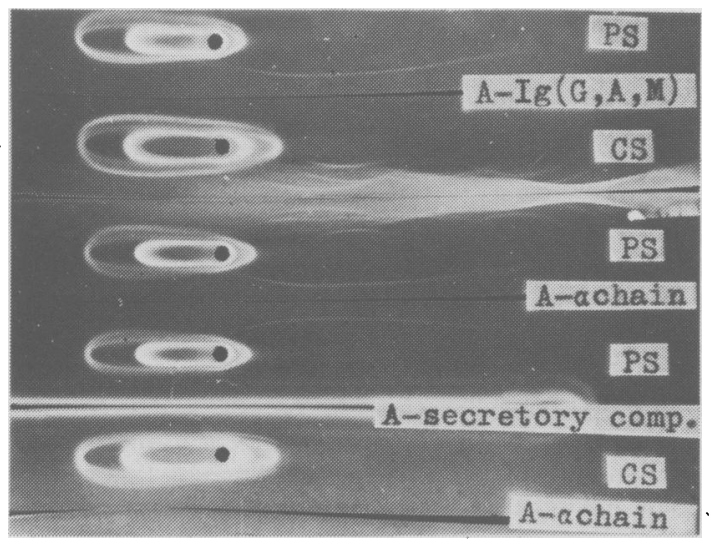

Fig. 1 Immunoselection plates showing the presence of alpha chain free of light chain. PS: patient serum; CS: control serum.

Fig. 2 Endoscopic features of the duodenal ulcer. Active ulcer with fold convergence is indicated.

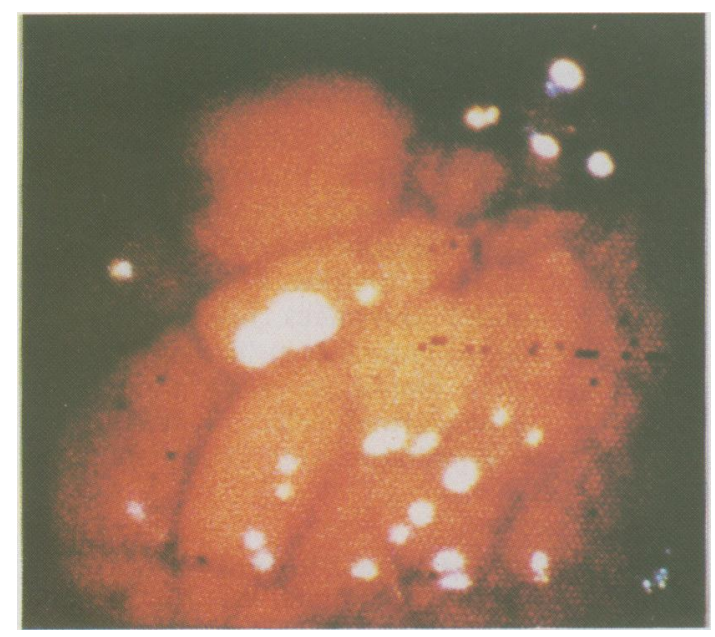

Fig. 3 Endoscopic features of the jejunal mucosa. A cobblestone-like appearance with small nodules along the whole small intestine is observed.

Their nuclei were oval, with peripheral clumps of chromatin. Nucleoli were also abundant. The welldeveloped Golgi apparatus and dilatation of roughsurfaced endoplasmic reticulum, which suggested an increase of secretory activity, were observed in the cytoplasm (Fig. 7a). Some of the rough-surfaced endoplasmic reticulum was arranged in unusual whorl-like configurations (Fig. 7b).
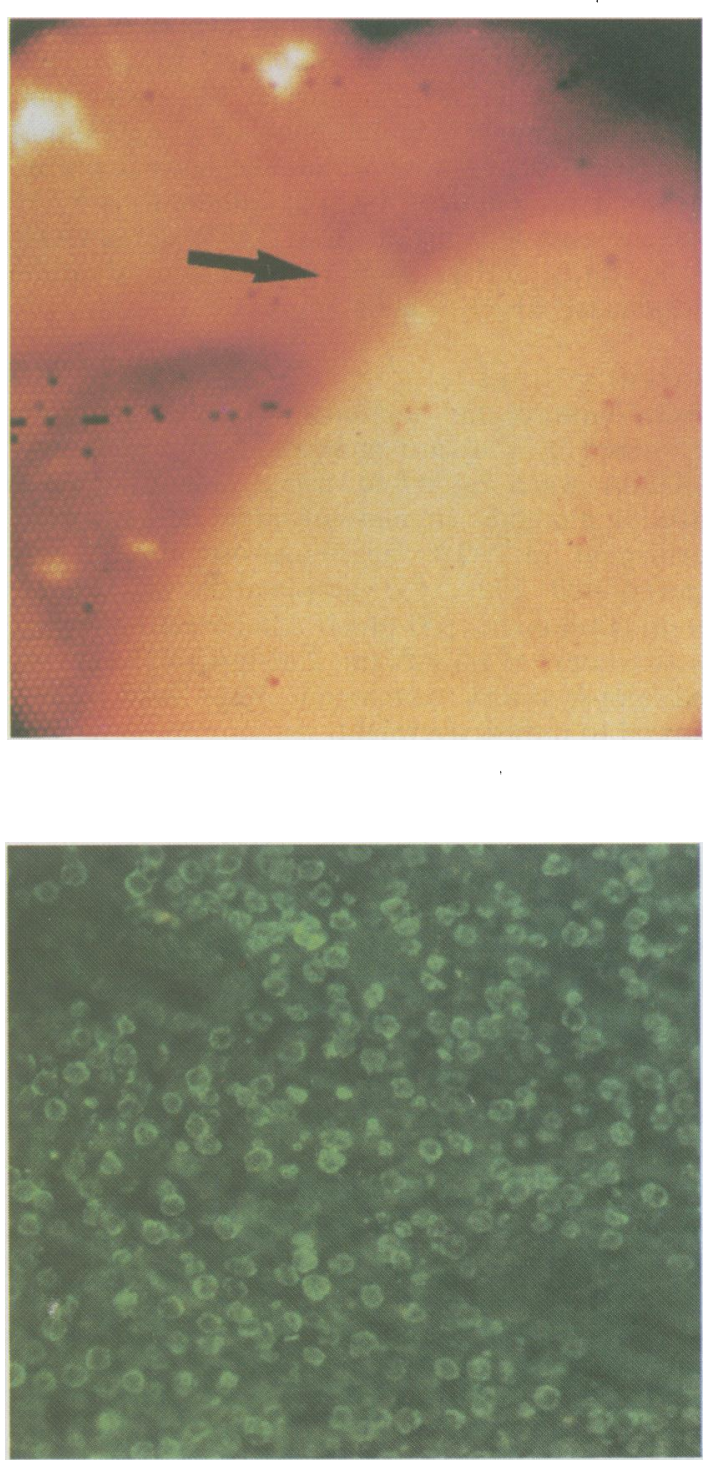

Fig. 4 Alpha chain containing cells in the biopsied jejunal mucosa, using anti-alpha chain serum conjugated with FITC. Numerous alpha chain cells are seen in the lamina propria, but no alpha chain is localised in the epithelial cells. $\times 200$ (original magnification).

\section{Discussion}

Alpha heavy chain disease is characterised by plasmacytic infiltration of the small intestine, the cells of which are considered to secrete an abnormal protein related to the alpha heavy chain of the $\operatorname{Ig} \mathrm{A}_{1}$ subclass. ${ }^{4}$ The patients with alpha heavy chain disease described since $1968^{1}$ have characteristically 

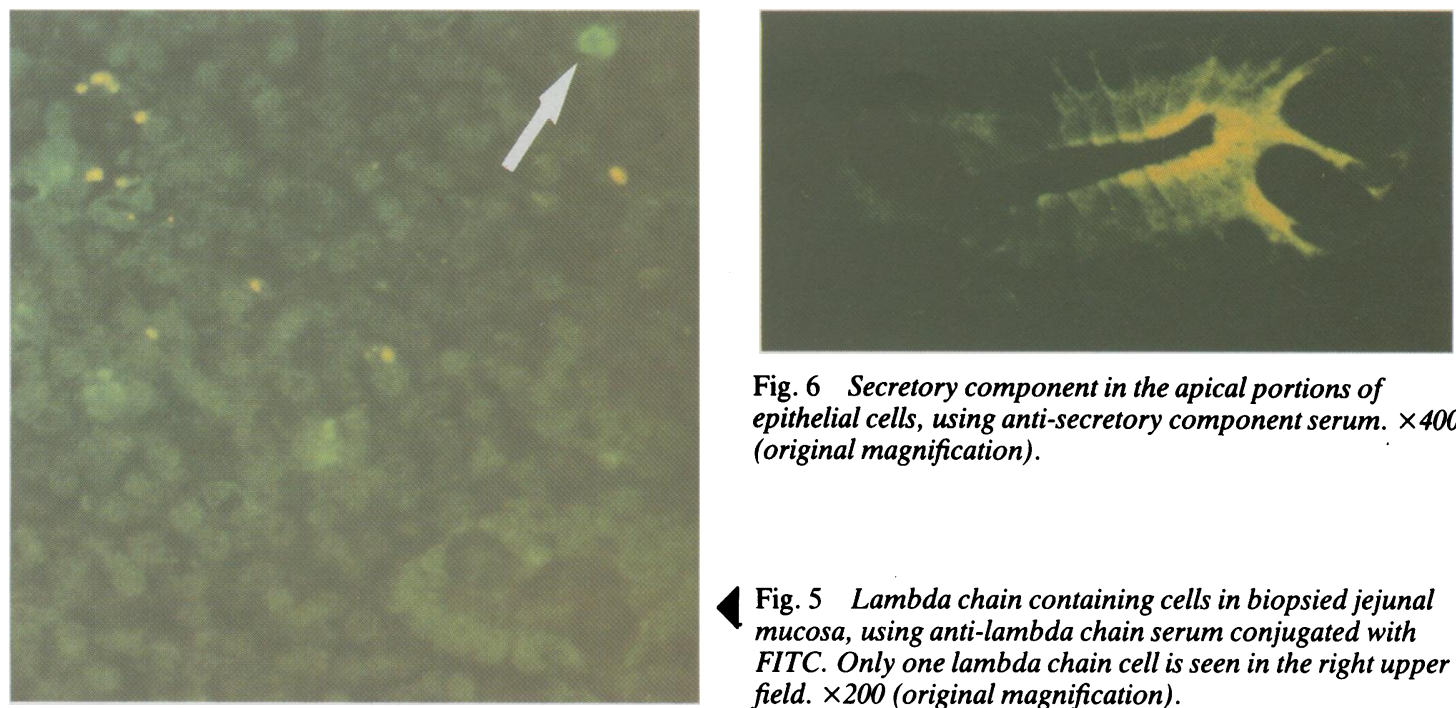

Fig. 6 Secretory component in the apical portions of epithelial cells, using anti-secretory component serum. $\times 400$ (original magnification).

Fig. 5 Lambda chain containing cells in biopsied jejunal mucosa, using anti-lambda chain serum conjugated with FITC. Only one lambda chain cell is seen in the right upper field. $\times 200$ (original magnification).

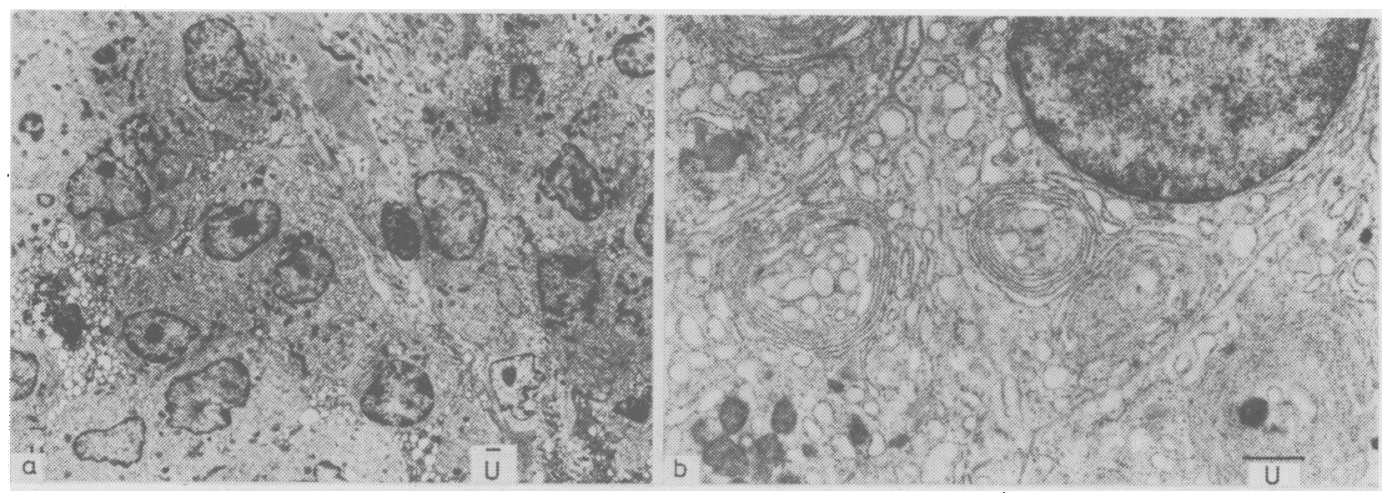

Fig. 7 Electron microscopic appearance of the infiltrating cells into the lamina propria. (a). The cells are chiefly mature plasma cells with well-developed Golgi apparatus and rough-surfaced endoplasmic reticulum. The cells have large nucleus and prominent nucleoli with peripheral clumps of chromation. $\times 3600$ (original magnification). (b) The cells have the whorl-like configurations of rough-surfaced endoplasmic reticulum. $\times 13000$ (original magnification).

been young and have come predominantly from the Middle East and Mediterranean areas. For this reason, it is important to report new cases outside these areas. In Japan, only three cases with alpha heavy chain disease, including our case, have been reported. ${ }^{23}$ Currently, the view is widely held that alpha heavy chain disease occurs as a reaction to chronic stimulation of the intestinal tract, because of the marked plasma cell infiltration and because the disease mainly occurs in areas of poor hygiene and with a high incidence of parasitic infiltration. Increase of epsilon chain cells, however, which has often been noted in cases of parasitic infection, was not observed in the present patient's intestine.
Endoscopic examination of the upper gastrointestinal tract has never been reported previously, although there have been some descriptions of the colonic lesions of alpha heavy chain disease. ${ }^{5-8}$ Among reported cases whose stomach was studied by radiographic examination, ${ }^{9-11}$ none revealed gastric lesions, such as multiple erosion, except for one case in which polyposis was found in the stomach. ${ }^{12}$ An association with duodenal ulcer was reported in two cases. ${ }^{1314}$ Studies on the stomach and duodenum in alpha heavy chain disease thus appear to be incomplete based on the literature (Table). The fact that multiple gastric erosion and duodenal ulcer were observed in the present patient 
Table Clinical and immunochemical studies of alpha heavy chain disease in literature

\begin{tabular}{|c|c|c|c|c|c|c|c|}
\hline \multirow[b]{2}{*}{ Authors } & \multirow{2}{*}{$\begin{array}{l}\text { GI tract lesions } \\
\text { except in small } \\
\text { intestine }\end{array}$} & \multirow[b]{2}{*}{ Authors } & \multicolumn{2}{|c|}{$\begin{array}{l}\text { Immunohistochemical studies } \\
\text { on intestinal mucosa }\end{array}$} & \multirow[b]{2}{*}{ Authors } & \multicolumn{2}{|c|}{ Salivary or jejunal fluids } \\
\hline & & & $\begin{array}{l}\text { Alpha } \\
\text { chain cells }\end{array}$ & $\begin{array}{l}\text { Secretory } \\
\text { component }\end{array}$ & & $\begin{array}{l}\text { Alpha chain } \\
\text { protein }\end{array}$ & $\begin{array}{l}\text { Binding } \\
\text { with } S C\end{array}$ \\
\hline $\begin{array}{l}\text { Rambaud }^{13} \\
(1968)\end{array}$ & Duodenal ulcer & $\begin{array}{l}\text { Seligmann } \\
\text { (1969) }\end{array}$ & Variable & $\mathrm{nd}^{*}$ & $\begin{array}{l}\text { Rambaud } \\
(1968)\end{array}$ & + & + \\
\hline $\begin{array}{l}\text { Manousos } 9 \\
(1974)\end{array}$ & $\begin{array}{l}\text { Nodular appearance } \\
\text { in rectum }\end{array}$ & $\begin{array}{l}\text { Doe }^{20} \\
(1972)\end{array}$ & Variable & nd & $\begin{array}{l}\text { Stoop } 22 \\
(1971)\end{array}$ & Normal IgA & + \\
\hline $\begin{array}{l}\text { Plesnicár }{ }^{5} \\
\text { (1975) }\end{array}$ & $\begin{array}{l}\text { Numerous ulcerated } \\
\text { nodules in colon }\end{array}$ & $\begin{array}{l}\text { Manousos } 9 \\
(1974)\end{array}$ & Absent & nd & $\begin{array}{l}\text { Doe }^{20} \\
(1972)\end{array}$ & + & - \\
\hline $\begin{array}{l}\text { Shulmann } \\
\text { (1975) }\end{array}$ & $\begin{array}{l}\text { Multiple mucosal } \\
\text { micro-ulcers in colon }\end{array}$ & $\begin{array}{l}\text { Shulmann } \\
\text { (1975) }\end{array}$ & Absent & nd & $\begin{array}{l}\text { Manousos } \\
(1974)\end{array}$ & + & nd \\
\hline $\begin{array}{l}\text { Tabbane }^{7} \\
\text { (1976) }\end{array}$ & $\begin{array}{l}\text { Tumour involvement } \\
\text { in colon }\end{array}$ & $\begin{array}{l}\text { Wang } \\
(1976)\end{array}$ & Numerous & nd & $\begin{array}{l}\text { Doe }^{10} \\
(1975)\end{array}$ & + & nd \\
\hline $\begin{array}{l}\text { Doe }^{14} \\
(1976)\end{array}$ & Duodenal ulcer & $\begin{array}{l}\text { Galian'11 } \\
\text { (1977) }\end{array}$ & Numerous & nd & $\begin{array}{l}\text { Plesnicár }{ }^{5} \\
\text { (1975) }\end{array}$ & + & nd \\
\hline $\begin{array}{l}\text { Galian" } \\
\text { (1978) }\end{array}$ & $\begin{array}{l}\text { Polypoid features } \\
\text { in rectum }\end{array}$ & $\begin{array}{l}\text { Haghighi }^{18} \\
\text { (1978) }\end{array}$ & Numerous & nd & $\begin{array}{l}\text { Shulmann } \\
\text { (1975) }\end{array}$ & + & nd \\
\hline $\begin{array}{l}\text { Al-Bahrani }{ }^{8} \\
(1978)\end{array}$ & $\begin{array}{l}\text { Extensive colonic } \\
\text { ulcer }\end{array}$ & & & & $\begin{array}{l}\text { Haghshenass }{ }^{23} \\
\text { (1977) }\end{array}$ & $\begin{array}{l}+ \\
+\end{array}$ & $\begin{array}{l}\text { nd } \\
\text { nd }\end{array}$ \\
\hline $\begin{array}{l}\text { Cohen }^{12} \\
(1978)\end{array}$ & $\begin{array}{l}\text { Polypoid features in } \\
\text { stomach and colon }\end{array}$ & & & & $\begin{array}{l}\text { Gafter }^{24} \\
(1980)\end{array}$ & + & nd \\
\hline $\begin{array}{l}\text { Hibi } \\
(1981)\end{array}$ & $\begin{array}{l}\text { Multiple gastric } \\
\text { erosion and } \\
\text { duodenal ulcer }\end{array}$ & $\begin{array}{l}\text { Hibi } \\
(1981)\end{array}$ & Numerous & $\begin{array}{l}\text { Present in the } \\
\text { apical portions of } \\
\text { epithelial cells }\end{array}$ & & & \\
\hline
\end{tabular}

${ }^{*}$ nd: not done.

suggests a breakdown of the protection mechanisms of the gastroduodenal mucosa in this disorder. Furthermore, the endoscopic findings such as the cobblestone-like appearance in the jejunum simulate those of Crohn's disease. Wang (1976) ${ }^{15}$ reported an English patient with alpha heavy chain disease in whom the possibility of Crohn's disease was considered on the basis of a barium meal study. More precise study on the diagnosis of Crohn's disease with high serum $\operatorname{IgA}$ values is thus warranted.

Biosynthetic studies performed on lymphoplasmacytic cells and tumour cells from the gut of patients with alpha heavy chain disease have revealed the synthesis of alpha heavy chain protein. ${ }^{16}$ Immunofluorescence studies of the gut performed in patients with the 'benign phase' have usually shown slight cytoplasmic fluorescence with anti-alpha chain antisera and no fluorescence with anti-light chain antisera. ${ }^{11}$ On the other hand, in patients with the 'malignant phase' the infiltrating cells have been completely negative with all antisera. Judged by the earlier reports (Table), the population of alpha chain positive cells has been variable, as the cases were not classified as being either benign or malignant. ${ }^{15} 1718$ In our case, which was of the benign phase as confirmed by the histopathological and electron microscopic examinations, most of the infiltrating cells were positive with anti-alpha chain antiserum, and almost negative with anti-light chain antiserum. From these findings, it is presumed that alpha chain protein is synthesised by infiltrating lymphoplasmacytic cells.

Secretory component in the epithelial cells of the jejunum from patients with alpha heavy chain disease has not been described previously (Table). Our patient's epithelial cells in the crypt contained secretory component in their apical portions, but did not possess alpha heavy chain in the same portions, as demonstrated by immunofluorescence studies. Moreover, the lamina propria consisted of alpha heavy chain positive cells. These findings suggest that secretory component and alpha heavy chain are produced separately in the small intestine, and that an association between the two did not occur in the present patient. This conflicts with the earliest report $^{13}$ that the jejunal fluid from alpha heavy chain disease contained alpha heavy chain protein associated with secretory component, but agrees with another report ${ }^{20}$ that jejunal fluid from the patient did not contain secretory component (Table). These conflicting data remain unresolved. One possibility is that alpha heavy chain protein cannot possess the double $\mathrm{Y}$ configuration as in the structure of normal secretory $\operatorname{IgA},{ }^{21}$ and that such structural alteration may cause difficulty for secretory component to bind alpha chain protein. Another possibility is that $\mathrm{J}$ chain might not be 
produced in the plasmacytoid cells in this disorder. $\mathrm{J}$ chain is considered to be necessary for the binding of alpha heavy chain and secretory component. Unfortunately, we were unable to study $J$ chain because of a shortage of purified anti-J chain antiserum.

In order to clarify the problem of binding, it is necessary to demonstrate secretory alpha chain localised in the intestinal epithelial cells. It is well established that IgA is synthesised by intestinal plasma cells and then binds to secretory component produced by epithelial cells in the normal intestine. ${ }^{25}$ Our findings suggest that secretory IgA or secretory alpha chain might not be produced in the intestine in the present patient. The absence of secretory alpha chain may cause a breakdown of the mucosal defence and render it easy for intestinal bacteria or viruses to invade the mucosa, although the role of alpha heavy chain protein devoid of light chain as antibody is unclear. This condition leads to a chance of intestinal tract stimulation and such weak mucosal defence mechanisms result in hypersusceptibility to intestinal stimulants and overproduction of useless alpha heavy chain secreting cells.

\section{References}

1 Seligman M, Danon F, Hurez D, Mihaesco E. Preud'homme, J. Alpha chain disease: a new immunoglobulin abnormality. Science 1968; 162: 1396-7.

2 Kitani T, Yatoh M, Yonezawa T, et al. Alpha chain disease. Sogorinsho 1973; 22: 1644-50. (In Japanese).

3 Saruta E, Miyamoto Y, Ito Y, Kawano K, Tsuchiya T, Oshima S. Alpha chain disease. Rinshomeneki 1976; 8: 643-9. (In Japanese).

4 Seligmann M. Immunochemical, clinical, and pathological features of alpha-chain disease. Arch Intern Med 1975; 135: 78-82.

5 Presnicár S, Sumi-Kriznik T, Golouh R. Abdominal lymphoma with alpha-heavy chain disease. Israel J Med Sci 1975; 11: 832-7.

6 Shulmann G, Laiyork E, Grive S. Alpha chain disease in a non-Mediterranean climate. $S$ Afr Med J 1975; 49: 2183-6.

7 Tabbane S, Tabbane F, Cammoun M, Mourai N. Mediterranean lymphomas with alpha heavy chain monoclonal gammanopathy. Cancer 1976; 38: 1989-96.

8 Al-Bahrani $\mathrm{Z}$, Al-Saleem $\mathrm{T}$, Al-Mondhiry $\mathrm{H}$, et al. Alpha heavy chain disease (report of 18 cases from Iraq). Gut 1978; 19: 627-31.

9 Manousos ON, Economidou JC, Georgiadou DE, et al. Alpha chain disease with clinical, immunological, and histological recovery. $\mathrm{Br} \mathrm{Med} J$ 1974; 2: 409-12.
10 Doe WF. Alpha chain disease. Clinicopathological features and relationship to so-called Mediterranean lymphoma. Br J Cancer 1975; 31: 350-5.

11 Galian A, Lecestre MJ, Scotto J, Bongel C, Matuchansky C, Rambaud JC. Pathological studies of alpha-chain disease, with special emphasis on evolution. Cancer 1977; 39: 2081-101.

12 Cohen HJ, Gonzallvo A, Krook J, Thompson TT, Kremer WB. New presentation of alpha heavy chain disease: North American polypoid gastrointestinal lymphoma. Cancer 1978; 41: 1161-9.

13 Rambaud JC, Bongel C, Prost A, et al. Clinicopathological study of a patient with 'Mediterranean' type of abdominal lymphoma and a new type of IgA abnormality ('Alpha chain disease'). Digestion 1968; 1: 321-36.

14 Doe WF, Henry K, Doyle FH, et al. Radiological and histological findings in six patients with alpha-chain disease. Br J Radiol 1976; 49: 3-11.

15 Wang SWS. Alpha-chain disease in an Englishman. Postgr Med J 1976; 52: 798-800.

16 Ramot B, Lievanton M, Hohn Y, Lahat N, Maroz C. The mutual clonal origin of the lymphoplasmocytic and lymphoma cell in alpha-heavy chain disease. Clin Exp Immunol 1977; 27: 440-5.

17 Skinner JM, Manousos UN, Economidou J, Nicolaou A, Meriskas G. Alpha-chain disease with localized plasmacytoma of the intestine. Immunoperoxidase study. Clin Exp Immunol 1976; 25: 112-6.

18 Haghighi P, Tabei Z, Kharazmi A, Gerami S, Abdadi $\mathrm{P}$, Haghshenass $\mathbf{M}$. Immunoperoxidase study in alphachain disease. Arch Pathol Lab Med 1978; 102: 555-7.

19 Seligman M, Mihaesco E, Hurez D, Mihaesco C, Preud'homme J, Rambaud JC. Immunochemical studies in four cases of alpha chain disease. J Clin Invest 1969; 48: 2374-89.

20 Doe WF, Henry K, Hobbs JR, Avery Jones F, Dent $\mathrm{CE}$, Booth CC. Five cases of alpha chain disease. Gut 1972; 13: 945-7.

21 Bloth B, Svehag S-E. Further studies on the ultrastructure of dimeric IgA of human origin. J Exp Med 1971; 133: 1035-42.

22 Stoop JW, Ballieux RE, Hijmans W, Zegers JM. Alpha-chain disease with involvement of the respiratory tract in a Dutch child. Clin Exp Immunol 1971; 9: 625-35.

23 Haghshenass M, Haghighi P, Abdadi P, Kharazmi A, Gerami C, Nasr K. Alpha-heavy chain disease in Southern Iran. Am J Dig Dis 1977; 22: 866-73.

24 Gafter U, Kessler E, Shabtay F, Shaked P, Djaldett M. Abnormal chromosomal marker $\left(D_{14} q+\right)$ in patient with alpha heavy chain disease. J Clin Pathol 1980; 33: 136-44.

25 Brantzaeg P. Mucosal and glandular distribution of immunoglobulin components. Immunohistochemistry with a cold ethanol fixation technique. Immunology 1974; 26: 1101-14.

26 Brown WR, Isobe K, Nakane PK, Pacini B. Studies on translocation of immunoglobulins across intestinal epithelium. IV. Evidence for binding of $\operatorname{IgA}$ and IgM to secretory component in intestinal epithelium. Gastroenterology 1977; 73: 1333-9. 